\title{
Laura Evans
}

\section{Supervisors as mentors}

How supervisory mentorship can supplement formal mentoring programs

B

inghamton University Libraries' mentoring program has been in place since 2006. The goals of this program are to orient new librarians to the organizational culture by building relationships with more senior librarians, and to help new librarians achieve tenure by providing support and advice on job performance, service, and scholarship throughout the six years leading to tenure review.

Initially, two mentors were provided for each new librarian from among the existing library faculty members. In 2018, an increase of new hires prompted us to think about how the mentoring program could be strengthened and refreshed to support the current balance of experience among library faculty members. There were several challenges that needed to be addressed, including a shortage of qualified mentors (those librarians who have passed the three-year review as part of the tenure process), and how to support the new librarians' needs and interests that do not necessarily align with the expertise of the available mentors. We concluded that our mentoring program could be reduced to one formal mentor and supplemented by other possible sources of mentorship, such as supervisory mentoring.

Leveraging supervisory mentoring within the libraries made sense because as we have made new hires, we have also moved from a flat to a more hierarchical structure, resulting in an increase in the number of librarians with supervisory responsibilities. A large part of the responsibility of any supervisor is to ensure the success of their employees, thus contributing to the success of the organization. Since librarians at Binghamton are tenure-track faculty, success entails fulfilling the requirements for tenure and promotion. While formal mentors are expected to help new librarians along in the tenure process, supervisors also play a significant role, which needs to be recognized.

Job performance is the most important factor in a librarian's review, and in most cases the supervisor is heavily relied upon to evaluate that performance. Since scholarship and service are often related to the functional areas in which librarians work, supervisors may also have more knowledge of these particular areas than the assigned mentors.

Our recommendations for how supervisors may mentor new librarians can be applicable in libraries that have formal mentoring programs, in which the supervisor acts in addition to a formal mentor, or in libraries without formal mentoring programs, in which the supervisor acts in the absence of a formal mentor. Either way, supervisors have to be careful of the risks of supervisory mentoring, such as obscuring the hierarchical supervisor/supervisee relationship. ${ }^{1}$ Supervisors are suited to provide the career functions of mentoring, which help mentees to succeed as professionals in the organization, but may want to forgo providing psychological functions of mentoring, such as friendship and

Laura Evans is metadata librarian and assistant head of cataloging at Binghamton University, email: evans@ binghamton.edu

(c) 2019 Laura Evans 
counseling, which can complicate the supervisory relationship. ${ }^{2}$

\section{Job performance}

Perhaps the most obvious way supervisors can mentor new librarians is by providing guidance on job duties and performance. This goes beyond ensuring that new librarians receive the functional training necessary to carry out job duties, and is different from evaluating performance. Rather, as mentors, supervisors can guide and encourage their employees' growth and development within their positions and within the profession.

Supervisors can begin to mentor new librarians by providing a strong foundation during the onboarding process. Binghamton has recently developed a new employee orientation checklist, which helps supervisors remember what new employees need to know, resulting in a more consistent orientation experience. Beyond the steps outlined on the checklist, supervisors should help new librarians understand their roles in the department and the organization, including the structure and goals of each. Not only is it important for new employees to understand the workflows of how daily tasks get accomplished, but also how people and units work together to achieve overall goals.

Learning who does what is one of the first challenges faced by all new employees, so supervisors can assist by making introductions and explaining the structure of the organization, which aids the onboarding process. Learning who does what and why (i.e., providing context and organizational history) can also help new employees feel a sense of belonging, as well as get a sense of the organizational politics. Similarly, orienting new librarians to ongoing projects can help them understand how they fit into the organization. Providing background on the goals, status, workflows, documentation, and people involved in each project will enhance new librarians' ability to successfully contribute.

For both job performance in general and for special projects in particular, supervisors can advise new librarians as to what roles they play in decision making, and how much initiative is expected. As they progress within these roles, supervisors can encourage them to continue developing skills and expertise, and can help identify leadership opportunities. Encouraging employees to take on leadership roles, at least for small projects, helps them feel valued by both their supervisors and the organization. In the dual roles of supervisor and mentor, supervisors may have the power to assign leadership roles where other mentors could not. By showing confidence in their employees' abilities and offering support, supervisors can inspire new librarians to develop their leadership skills.

Furthermore, talking to new employees early on about what strengths they bring to the organization can help them identify opportunities to use those strengths in their positions, and to be more confident in participating in the organization. ${ }^{3}$ As librarians progress in their careers, supervisors can work with them to identify areas of potential growth, and support training and professional development in areas that will benefit both the employees and the organization.

\section{Scholarship and service}

Librarians at Binghamton University are required to show achievement in scholarship and service in addition to job performance. It is part of the library faculty mentor's duties to advise their mentee on these aspects, but supervisors also have something to offer in terms of mentorship in these areas. Navigating the requirements of tenure is never easy, and it helps to have multiple sources of advice and encouragement.

Supervisors can play an important role in making the expectations for scholarship and service clear to new librarians from the beginning. In an environment where publication is a requirement for tenure, it is especially important to encourage new librarians to think about scholarship as early as possible, so that they will have sufficient time to research, write, and publish. While it is not expected that supervisors will coresearch or copublish with new librarians, they can offer mentorship on possible research topics and can facilitate research conducted within the library. Supervisors can 
also advise their new employees about how much on-the-job time should be devoted to scholarship and service, and how to prioritize competing demands.

Supervisors can also help new librarians find appropriate professional organizations to enhance their professional development. New librarians may not be familiar with all of the professional organizations relevant to their field or be subscribed to the listservs where conferences and calls for presentations are advertised, so supervisors who have been in the field longer can provide suggestions based on their own experiences. Encouraging new librarians to become involved with professional organizations, attend conferences, and learn from others within the field, can be an important step in developing scholarship and professional identity. Supervisors can offer advice on how to get involved with professional service and share information on professional organizations' structures, volunteer cycles, and networking opportunities, which can help new librarians feel more comfortable with the service expectation. Advice on how much service is appropriate and how much time and travel are required can also help new librarians identify opportunities that meet their needs.

Finally, one of the most important ways supervisors can act as mentors is to encourage employees to seek out other mentors for specific interests and continued professional development. No one mentor can or should guide all aspects of an individual employee's professional development, so encouraging new librarians to build a network of mentors as they progress through their careers will help them to grow in different aspects, develop individual interests and expertise, and more fully engage with the profession.

\section{Conclusion}

While all new librarians at Binghamton University are provided with a formal mentor from among the library faculty, supervisors are encouraged to recognize that they are also mentors to their new employees. By recognizing that they are often fulfilling the role of mentor, supervisors can be more deliberate in offering advice and guidance. Supervisors are often the primary figures in the work lives of new employees and who they will naturally turn to for guidance on job duties and orientation within the organization. If it is clear that supervisors can also function as mentors in the ways outlined in this article, there will be less confusion about who can answer questions, and perhaps less self-consciousness in seeking guidance. This will lead to healthier relationships, stronger employees, and a better organization overall.

As an organization, Binghamton University Libraries is invested in retaining the librarians we recruit, and are therefore continually trying to improve the mentorship experience for new librarians. Since the formal mentoring program began, we have revised it several times. We need to continue to help both formal mentors and supervisors be better prepared for their roles, and explore how to best mentor the mentors. Our next step will be to conduct an assessment of the mentoring program. We hope to use the feedback to determine how to improve the administrative foundation of our mentoring program, as well as spark additional ideas of how to supplement the program, such as recognizing supervisors as mentors.

\section{Notes}

1. Rosemary Booth, "Mentor or Manager: What Is the Difference? A Case Study in Supervisory Mentoring," Leadership \& Organization Development Journal 17, no. 3 (1996): 31-36.

2. Deborah Hicks, Jeanette Buckingham, and Margaret Law, "Mentoring and Supervision? Or, Mentoring Versus Supervision?" in Recruitment, Development, and Retention of Information Professionals: Trends in Human Resources and Knowledge Management, eds. Elisabeth Pankl, Danielle ThiessWhite, and Mary C. Bushing (New York: IGI Global, 2010), 251-66.

3. Bruce Keisling and Melissa Laning, "We Are Happy To Be Here: The Onboarding Experience in Academic Libraries," Journal of Library Administration 56 (2016): 381-94. 22 